\title{
Alkali Cation Potential and Functionality in the Nanoporous Prussian Blue Analogues
}

\author{
Yutaka Moritomo $^{1,2}$ and Hiroshi Tanaka ${ }^{3}$ \\ ${ }^{1}$ Graduate School of Pure and Applied Science, University of Tsukuba, Tsukuba, Ibraki 305-8577, Japan \\ ${ }^{2}$ Tsukuba Research Center for Interdisciplinary Materials Science (TIMS), University of Tsukuba, Tsukuba, Ibraki 305-8577, Japan \\ ${ }^{3}$ Department of Materials Science, Shimane University, Matsue, Shimane 690-8504, Japan
}

Correspondence should be addressed to Yutaka Moritomo; moritomo@sakura.cc.tsukuba.ac.jp

Received 1 October 2012; Revised 17 January 2013; Accepted 10 February 2013

Academic Editor: Michael C. Tringides

Copyright ( $) 2013$ Y. Moritomo and H. Tanaka. This is an open access article distributed under the Creative Commons Attribution License, which permits unrestricted use, distribution, and reproduction in any medium, provided the original work is properly cited.

Cation and/or molecule transfer within nanoporous materials is utilized in lithium-ion secondary battery, ion exchange, hydrogen storage, molecular sensors, molecular filters, and so on. Here, we performed ab initio total energy calculation to derive the alkali cation potential in the Prussian blue analogues, $\mathrm{A}_{x} \mathrm{M}\left[\mathrm{Fe}(\mathrm{CN})_{6}\right]_{y} z \mathrm{H}_{2} \mathrm{O}(\mathrm{A}=\mathrm{Li}, \mathrm{Na}, \mathrm{K}, \mathrm{Rb}$, and Cs; $\mathrm{M}=\mathrm{Co}, \mathrm{Ni}, \mathrm{Mn}, \mathrm{and} \mathrm{Cd})$, with jungle-gym-type nanoporous framework. The potential curves of larger cations, that is, $\mathrm{K}^{+}, \mathrm{Rb}^{+}$and $\mathrm{Cs}^{+}$, exhibit a barrier at the window of the host framework, while those of the smaller cations, that is, $\mathrm{Li}^{+}$and $\mathrm{Na}^{+}$, exhibit no barrier. We will discuss the useful functionalities observed in the Prussian blue analogues, that is, (a) battery properties mediated by $\mathrm{Li}^{+}$intercalation/deintercalation, (b) electrochromism mediated by $\mathrm{Na}^{+}$transfer in all solid device, and (c) the elimination of $\mathrm{Cs}^{+}$from aqueous solution by precipitation, in terms of the alkali cation potentials.

\section{Introduction}

Nanoporous materials are attracting the increasing interest of material scientists because the materials are utilized in lithium-ion battery, ion exchange, hydrogen storage, molecular sensors, and molecular filters, and so on. To further improve the functionality, we need to comprehend the cation and molecular routes and their potential within the host framework. Among the nanoporous materials, the Prussian blue analogues, $\mathrm{A}_{x} \mathrm{M}\left[\mathrm{Fe}(\mathrm{CN})_{6}\right]_{y} z \mathrm{H}_{2} \mathrm{O}$ ( $\mathrm{A}$ and $\mathrm{M}$ are alkali metal and transition metal, resp.), are attracting current interest of material scientists because they exhibit useful functionalities, such as battery properties mediated by $\mathrm{Li}^{+}$ intercalation [1-8], electrochromism mediated by $\mathrm{Na}^{+}$intercalation [9-16], and the elimination of $\mathrm{Cs}^{+}$from aqueous solution by precipitation [17]. The Prussian blue analogue is the oldest complex compound that the human being synthesized. The compound is easily synthesized from cheap and ubiquitous source materials and, hence, has great advantage for commercial use of the above-mentioned functionalities.
The Prussian blue analogue, $\mathrm{A}_{x} \mathrm{M}\left[\mathrm{Fe}(\mathrm{CN})_{6}\right]_{y} z \mathrm{H}_{2} \mathrm{O}$, consists of a three-dimensional (3D) cyano-bridged transition metal framework $\left(\mathrm{M}\left[\mathrm{Fe}(\mathrm{CN})_{6}\right]_{y}\right)$ and guests $\left(\mathrm{A}^{+}\right.$and $\left.\mathrm{H}_{2} \mathrm{O}\right)$, as schematically shown in Figure 1. A part of the waters (ligand water: $\mathrm{H}_{2} \mathrm{O}_{1}$ ) locates at the $\left[\mathrm{Fe}(\mathrm{CN})_{6}\right]$ vacancies and coordinates to the transition metal. The residual waters (zeolite water: $\mathrm{H}_{2} \mathrm{O}_{z}$ ) and alkali cations $\left(\mathrm{A}^{+}\right.$) locate in the nanocubes of the host framework. Most of the Prussian blue analogues exhibit the face-centered cubic structure $(F m \underline{3} m$; $Z=4)[18]$.

The framework size of the nanocube can be finelycontrolled by the substitution of $\mathrm{M}$, whose ionic size $\left(r_{\mathrm{M}}\right)$ changes from $r_{\mathrm{M}}=0.061 \mathrm{~nm}$ for $\mathrm{Fe}^{2+}$ to $0.083 \mathrm{~nm}$ for $\mathrm{Mn}^{2+}$. As shown in Figure 2(a), the magnitude of $a$ increases linearly with $r_{\mathrm{M}}$ as $[\mathrm{nm}]=0.891+2 r_{\mathrm{M}}[\mathrm{nm}]$ in $(\mathrm{Cs}, \mathrm{Rb})_{x} \mathrm{M}^{\mathrm{II}}\left[\mathrm{Fe}^{\mathrm{III}}(\mathrm{CN})_{6}\right]_{y}(\mathrm{M}=\mathrm{Co}, \mathrm{Fe}, \mathrm{Ni}, \mathrm{Cu}, \mathrm{Zn}, \mathrm{Mn}$, and $\mathrm{Cd}$ ) [18]. Incidentally, the lattice property of the host framework systematically changes with the framework size $(=a / 2)$. For example, the magnitude and sign of the thermal 


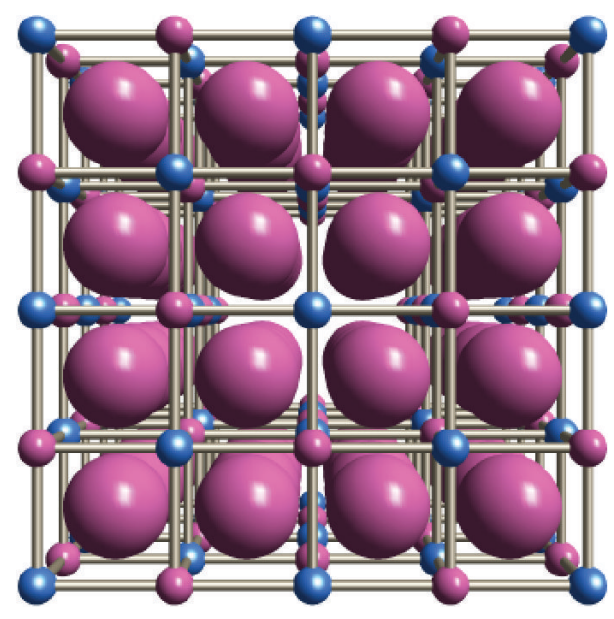

Figure 1: Schematic structure of the Prussian blue analogue, $\mathrm{A}_{x} \mathrm{M}\left[\mathrm{Fe}(\mathrm{CN})_{6}\right]_{y} z \mathrm{H}_{2} \mathrm{O}$ (A and $\mathrm{M}$ are alkali metal and transition metal, resp.). Transition metal and iron (small spheres) are alternatively bridged by the cyano groups (sticks). Large spheres represent the guest alkali cations. Water molecules are omitted for simplicity.

expansion coefficient $(\beta=d \ln a / d T)$ systematically change from positive to negative with increase in $a$ (Figure 2(b)). The behavior was explained by the steric hindrance effect of the rotational fluctuation of the $\left[\mathrm{Fe}(\mathrm{CN})_{6}\right]$ units [18]. The rotational fluctuation is suppressed in the small- $a$ compounds, causing the conventional positive thermal expansion.

Historically, cation transfer within the Prussian blue analogues is interpreted in terms of the hydrated radius $\left(r_{\mathrm{H}}\right)$ [19-22] rather than the ionic radius $\left(r_{\mathrm{A}}\right)$. This is because the Prussian blue analogues contain considerable amount of zeolite water, and hydration energy is needed to form a bare cation at the liquid-solid interface. Actually, Tieke's group $[21,22]$ reported that self-assembled films of the Prussian blue analogues are permeable to smaller hydrated ions such as $\mathrm{Cs}^{+}$ $\left(r_{\mathrm{H}}=0.119 \mathrm{~nm}\right)$ and $\mathrm{K}^{+}\left(r_{\mathrm{H}}=0.125 \mathrm{~nm}\right)$, whereas they block larger hydrated ions such as $\mathrm{Na}^{+}\left(r_{\mathrm{H}}=0.184 \mathrm{~nm}\right)$. These films, however, consist of microcrystals with considerable $\left[\mathrm{Fe}(\mathrm{CN})_{6}\right]$ vacancies $(y \sim 0.67)$. This suggests that the hydrated ions migrate along the vacancies and/or grain boundaries. Recently, Moritomo et al. [23] electrochemically synthesized a thin film of $\mathrm{Na}_{0.76} \mathrm{Co}\left[\mathrm{Fe}(\mathrm{CN})_{6}\right]_{0.90} 2.9 \mathrm{H}_{2} \mathrm{O}(y=$ $0.9)$ with fewer vacancies. In addition, the film consists of crystalline large rod-shaped grains and has few grain boundaries. They observed that the intercalation of $\mathrm{Na}^{+}\left(r_{\mathrm{A}}=\right.$ $0.118 \mathrm{~nm})$ is much faster than those of $\mathrm{K}^{+}\left(r_{\mathrm{A}}=0.151 \mathrm{~nm}\right)$ and $\mathrm{Rb}^{+}\left(r_{\mathrm{A}}=0.161 \mathrm{~nm}\right)$ in this film. This suggests that the cation transfer within the Prussian blue framework should be interpreted in terms of $r_{\mathrm{A}}$ of the bare cation: $\mathrm{Li}^{+}\left(r_{\mathrm{A}}=\right.$ $0.092 \mathrm{~nm}), \mathrm{Na}^{+}(0.118 \mathrm{~nm}), \mathrm{K}^{+}(0.151 \mathrm{~nm}), \mathrm{Rb}^{+}(0.161 \mathrm{~nm})$, and $\mathrm{Cs}^{+}(0.174 \mathrm{~nm})$.

In this paper, we performed ab initio total energy calculation in the Prussian blue analogues, $\mathrm{A}_{x} \mathrm{M}\left[\mathrm{Fe}(\mathrm{CN})_{6}\right]_{y} z \mathrm{H}_{2} \mathrm{O}$ $(\mathrm{A}=\mathrm{Li}, \mathrm{Na}, \mathrm{K}, \mathrm{Rb}$, and $\mathrm{Cs} ; \mathrm{M}=\mathrm{Co}, \mathrm{Ni}, \mathrm{Mn}$, and $\mathrm{Cd})$. The alkali cation potentials of larger $\mathrm{K}^{+}, \mathrm{Rb}^{+}$, and $\mathrm{Cs}^{+}$exhibit a potential barrier at the window of the host framework, while those of the smaller $\mathrm{Li}^{+}$and $\mathrm{Na}^{+}$exhibit no barrier. We will
TABLE 1: Structural parameters used in the $a b$ initio total energy calculation of $\mathrm{AMn}\left[\mathrm{Fe}(\mathrm{CN})_{6}\right](\mathrm{A}=\mathrm{Li}, \mathrm{Na}, \mathrm{K}, \mathrm{Cs}$, and $\mathrm{Rb})$. The lattice constants are $a=b=0.74730 \mathrm{~nm}$ and $c=1.056601 \mathrm{~nm}$.

\begin{tabular}{lccccc}
\hline Atom & Site & $g$ & $x$ & $y$ & $z$ \\
\hline Fe & $2 \mathrm{a}$ & 1 & 0 & 0 & 0 \\
$\mathrm{Mn}$ & $2 \mathrm{a}$ & 1 & 0 & 0 & $1 / 2$ \\
$\mathrm{C}$ & $8 \mathrm{e}$ & 1 & 0.32461 & 0.67539 & $1 / 2$ \\
$\mathrm{C}$ & $2 \mathrm{a}$ & 1 & 0 & 0 & 0.82461 \\
$\mathrm{C}$ & $2 \mathrm{a}$ & 1 & 0 & 0 & 0.17539 \\
$\mathrm{~N}$ & $8 \mathrm{e}$ & 1 & 0.20884 & 0.79116 & $1 / 2$ \\
$\mathrm{~N}$ & $2 \mathrm{a}$ & 1 & 0 & 0 & 0.70884 \\
$\mathrm{~N}$ & $2 \mathrm{a}$ & 1 & 0 & 0 & 0.29116 \\
$\mathrm{~A}$ & $2 \mathrm{~b}$ & 1 & $1 / 2$ & 0 & $z$ \\
\hline
\end{tabular}

discuss the useful functionalities observed in the Prussian blue analogues, that is, (a) battery properties mediated by $\mathrm{Li}^{+}$ intercalation/de-intercalation, (b) electrochromism mediated by $\mathrm{Na}^{+}$transfer in all solid device, and (c) the elimination of $\mathrm{Cs}^{+}$from aqueous solution by precipitation, in terms of the alkali cation potentials.

\section{Ab Initio Total Energy Calculation}

2.1. Method of Calculation. The ab initio total energy calculation was performed for an ideal Prussian blue lattice, that is, $\mathrm{AM}\left[\mathrm{Fe}(\mathrm{CN})_{6}\right](\mathrm{A}=\mathrm{Li}, \mathrm{Na}, \mathrm{K}, \mathrm{Rb}$, and $\mathrm{Cs} ; \mathrm{M}=\mathrm{Co}, \mathrm{Ni}$, $\mathrm{Mn}$, and $\mathrm{Cd}$ ), using the program package WIEN2k [24] for the full potential linear augmented wave (FLAPW) method. We employed a potential based on the generalized gradient approximation (GGA) proposed by Perdew et al. [25]. We confirmed that the final results are nearly independent of the approximation of the potential. The alkali cation potential corresponds to the total energy difference $\Delta E$ against the alkali cation coordinate $(z)$. In order to move the $\mathrm{A}^{+}$ion, tetragonal space group (Imm2: $Z=2$ ) was adopted instead of the actual cubic space group $(F m \underline{3} m ; Z=4) . z=0$ corresponds to the window position, as $z= \pm 1 / 4$ does to the nanocube center.

In the $\mathrm{Mn}$ and Co compounds, the actual lattice parameters, that is, $\mathrm{Na}_{1.32} \mathrm{Mn}\left[\mathrm{Fe}(\mathrm{CN})_{6}\right]_{0.83} \cdot 3.6 \mathrm{H}_{2} \mathrm{O} \quad(a=$ $1.056601 \mathrm{~nm})[26]$ at $340 \mathrm{~K}$ and $\mathrm{K}_{0: 34} \mathrm{Co}\left[\mathrm{Fe}(\mathrm{CN})_{6}\right]_{0: 75} \cdot 6 \mathrm{H}_{2} \mathrm{O}$ $(a=0.93440 \mathrm{~nm})[27]$ at $90 \mathrm{~K}$, were adopted (see Tables 1 and 2). The magnitude of $a(=1.05561 \mathrm{~nm})$ for $\mathrm{M}=\mathrm{Mn}$ is much larger than that $(=0.93440 \mathrm{~nm})$ for $\mathrm{M}=\mathrm{Co}$. In the Ni $(a=$ $1.02915 \mathrm{~nm})$ and $\mathrm{Cd}(a=1.0755 \mathrm{~nm})$ compounds, we used the same atomic coordinates as $\mathrm{M}=\mathrm{Mn}$.

2.2. Results and Discussion. Figure 3 shows total energy difference $\Delta E$ of (a) $\mathrm{AMn}\left[\mathrm{Fe}(\mathrm{CN})_{6}\right]$ and (b) $\mathrm{ACo}\left[\mathrm{Fe}(\mathrm{CN})_{6}\right]$ against cation coordinate $(z)$. The profile of the alkali cation potential is determined by the short-range atomic repulsive interaction as well as the long-range electrostatic interaction. In both materials, the potential curves for $\mathrm{K}^{+}, \mathrm{Rb}^{+}$, and $\mathrm{Cs}^{+}$ exhibit a barrier at $z=0$. The heights of the potential barrier $(\Delta)$ steeply decrease with the decrease in $r_{\mathrm{A}}$. The $\Delta$-values $(>0.3 \mathrm{eV})$ for $\mathrm{K}^{+}, \mathrm{Rb}^{+}$, and $\mathrm{Cs}^{+}$are much higher than the 


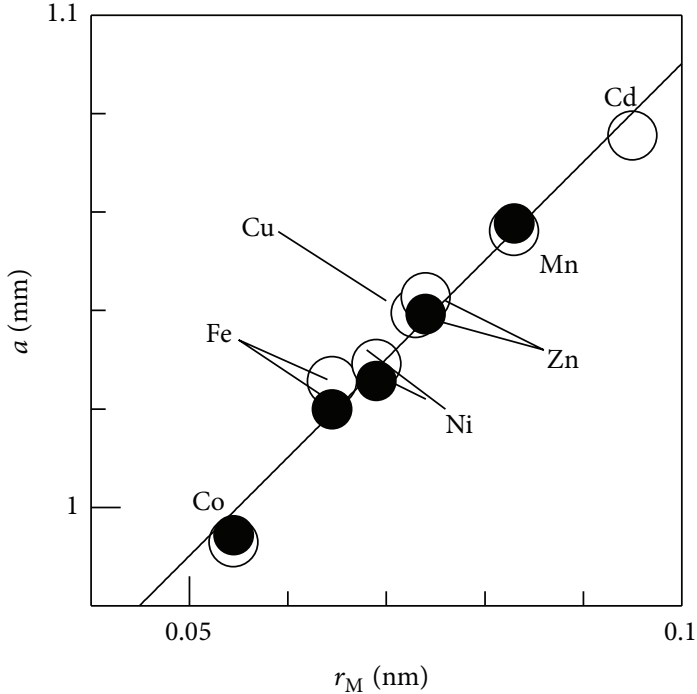

$\operatorname{RbM}\left[\mathrm{Fe}(\mathrm{CN})_{6}\right]$
$\mathrm{CsM}\left[\mathrm{Fe}(\mathrm{CN})_{6}\right]$

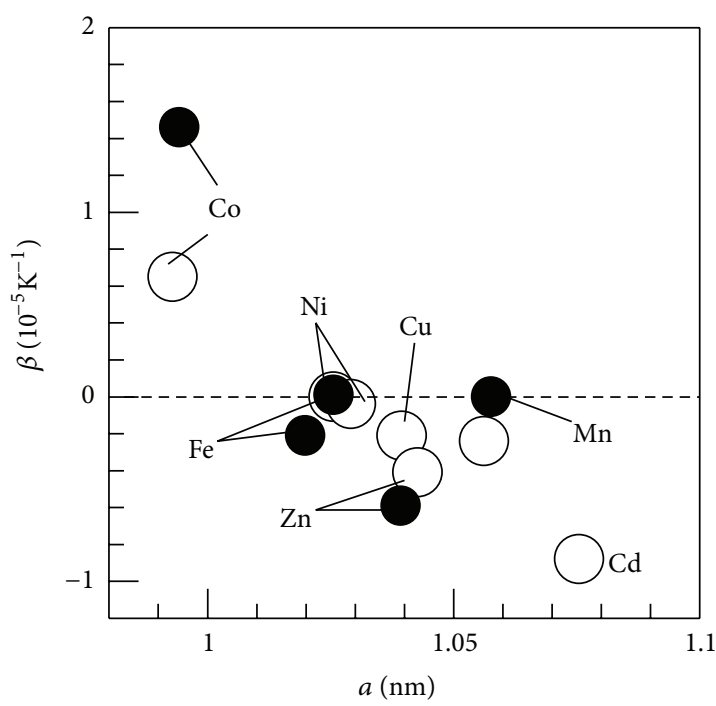

$\left(\begin{array}{l}\mathrm{RbM}\left[\mathrm{Fe}(\mathrm{CN})_{6}\right] \\ \mathrm{CsM}\left[\mathrm{Fe}(\mathrm{CN})_{6}\right]\end{array}\right.$

(a)

(b)

Figure 2: (a) Lattice constant (a) against ionic radius $\left(r_{\mathrm{M}}\right)$ of transition metal in the Prussian blue analogues. (b) Thermal expansion coefficient $(\beta=d \ln a / d T)$ against $a$ in the Prussian blue analogues. Solid line in (a) is the result of the least-squares fitting. Data were cited from [18].

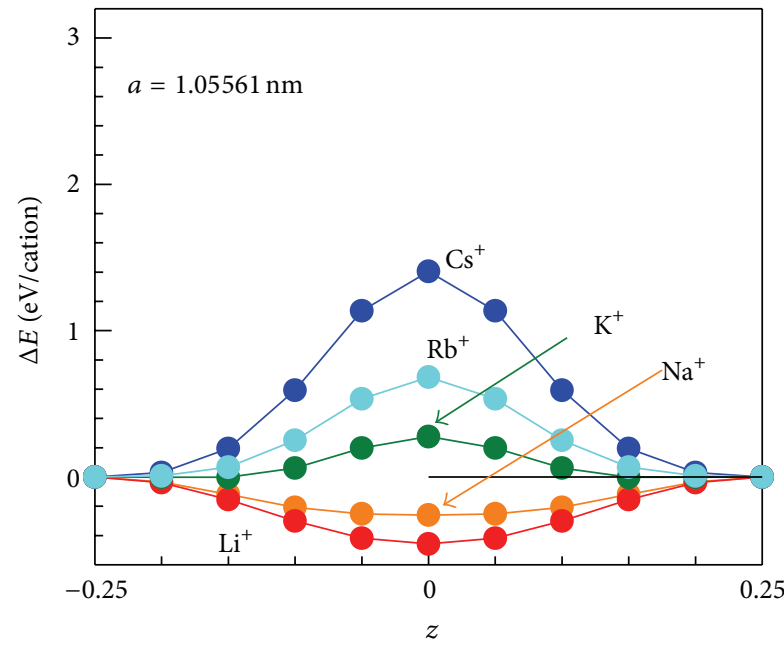

(a) $\mathrm{A}_{x} \mathrm{Mn}\left[\mathrm{Fe}(\mathrm{CN})_{6}\right] a=1.05561 \mathrm{~nm}$

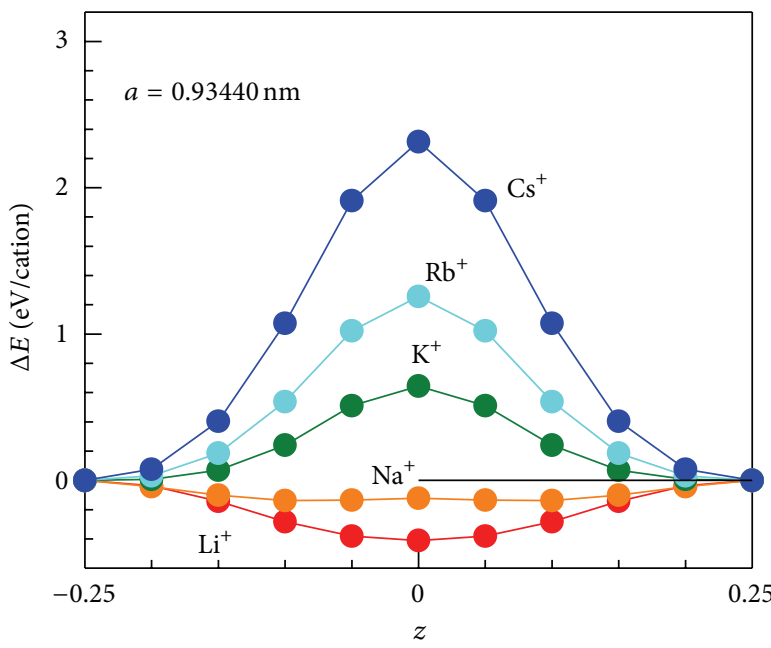

(b) $\mathrm{A}_{x} \mathrm{Co}\left[\mathrm{Fe}(\mathrm{CN})_{6}\right] a=0.93440 \mathrm{~nm}$

Figure 3: Total energy difference $\Delta E$ of (a) $\mathrm{AMn}\left[\mathrm{Fe}(\mathrm{CN})_{6}\right]$ and (b) $\mathrm{ACo}\left[\mathrm{Fe}(\mathrm{CN})_{6}\right]$ against cation coordinate $(z)$. $z=0$ corresponds to the window position, as $z= \pm 1 / 4$ does to the nanocube center.

thermal energy $(=0.03 \mathrm{eV})$ at room temperature, indicating that ionic migration is impossible. On the other hand, the potential curves for $\mathrm{Li}^{+}$and $\mathrm{Na}^{+}$have no barrier at $z=0$, indicating that these cations rapidly migrate within the host framework. Reflecting the smaller $a$-value of $\mathrm{ACo}\left[\mathrm{Fe}(\mathrm{CN})_{6}\right]$, the $\Delta-r_{\mathrm{A}}$ curve of $\mathrm{ACo}\left[\mathrm{Fe}(\mathrm{CN})_{6}\right]$ shifts toward the higher energy side (see Figure 4).

The $\mathrm{Li}^{+}$and $\mathrm{Na}^{+}$potential curves of $\mathrm{AMn}\left[\mathrm{Fe}(\mathrm{CN})_{6}\right]$ (see Figure 2(a)) exhibit local minima at the square window $(z=0)$. Similar trend is observed in the $\mathrm{Na}^{+}$potentials of $\mathrm{ACo}\left[\mathrm{Fe}(\mathrm{CN})_{6}\right]$ (see Figure 3(b)). These observations suggest that the central position $(z= \pm 1 / 4)$ of the nanocube is not the potential minima. The nanocube consists of four $\left[\mathrm{Fe}(\mathrm{CN})_{6}\right]^{3-}$ and four $\mathrm{M}^{2+}$, and, hence, the resultant electrostatic potential has $T_{d}$ symmetry. Then, the potential minimum is considered to be at the tetrahedral site toward the four $\left[\mathrm{Fe}(\mathrm{CN})_{6}\right]^{3-}$. Consistently, Moritomo et al. [26] performed structural analysis of $\mathrm{Na}_{1.32} \mathrm{Mn}\left[\mathrm{Fe}(\mathrm{CN})_{6}\right]_{0.83} \cdot 3.6 \mathrm{H}_{2} \mathrm{O}$ 
TABLE 2: Structural parameters used in the $a b$ initio total energy calculation of $\mathrm{ACo}\left[\mathrm{Fe}(\mathrm{CN})_{6}\right](\mathrm{A}=\mathrm{Li}, \mathrm{Na}, \mathrm{K}, \mathrm{Cs}$, and $\mathrm{Rb})$. The lattice constants are $a=b=0.66072 \mathrm{~nm}$ and $c=0.93440 \mathrm{~nm}$.

\begin{tabular}{lccccc}
\hline Atom & Site & $g$ & $x$ & $y$ & $z$ \\
\hline Fe & $2 \mathrm{a}$ & 1 & 0 & 0 & 0 \\
$\mathrm{Co}$ & $2 \mathrm{a}$ & 1 & 0 & 0 & $1 / 2$ \\
$\mathrm{C}$ & $8 \mathrm{e}$ & 1 & 0.31995 & 0.68005 & $1 / 2$ \\
$\mathrm{C}$ & $2 \mathrm{a}$ & 1 & 0 & 0 & 0.82461 \\
$\mathrm{C}$ & $2 \mathrm{a}$ & 1 & 0 & 0 & 0.17539 \\
$\mathrm{~N}$ & $8 \mathrm{e}$ & 1 & 0.20464 & 0.79536 & $1 / 2$ \\
$\mathrm{~N}$ & $2 \mathrm{a}$ & 1 & 0 & 0 & 0.70464 \\
$\mathrm{~N}$ & $2 \mathrm{a}$ & 1 & 0 & 0 & 0.29536 \\
$\mathrm{~A}$ & $2 \mathrm{~b}$ & 1 & $1 / 2$ & 0 & $z$ \\
\hline
\end{tabular}

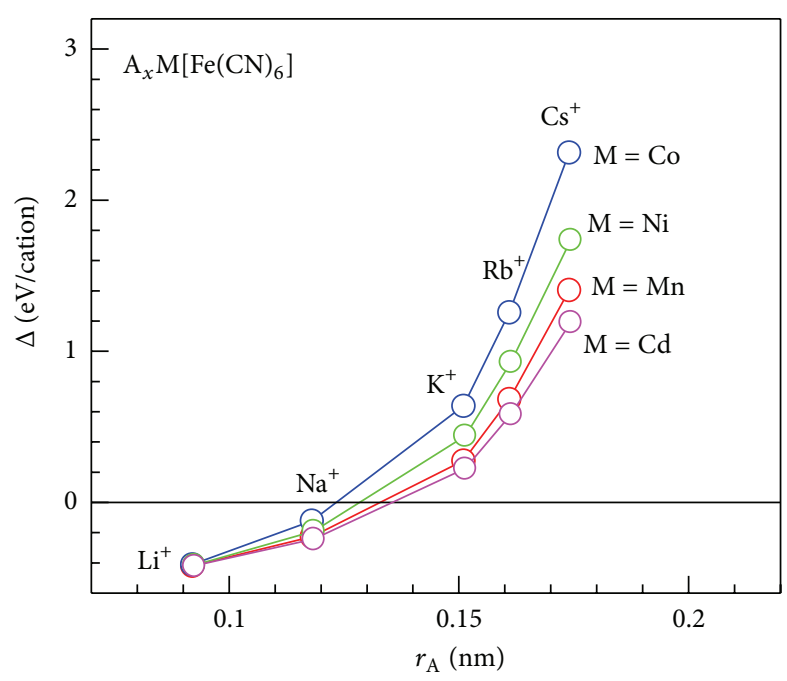

Figure 4: Potential barrier $(\Delta)$ at the window against ionic radius $\left(r_{\mathrm{A}}\right)$ of alkali cation in $\mathrm{AM}\left[\mathrm{Fe}(\mathrm{CN})_{6}\right](\mathrm{M}=\mathrm{Co}, \mathrm{Ni}, \mathrm{Mn}$, and $\mathrm{Cd})$.

at $300 \mathrm{~K}$ and found that $\mathrm{Na}^{+}$randomly occupies the tetrahedral site. The small ionic radius is considered to be a necessary condition for the tetrahedral displacement, since the larger ions feel short-range atomic repulsive interaction from the host framework. Actually, no displacement of $\mathrm{K}^{+}$is observed in $\mathrm{K}_{0: 34} \mathrm{Co}\left[\mathrm{Fe}(\mathrm{CN})_{6}\right]_{0: 75} \cdot 3.6 \mathrm{H}_{2} \mathrm{O}$ and $\mathrm{K}_{0: 34} \mathrm{Co}\left[\mathrm{Fe}(\mathrm{CN})_{6}\right]_{0: 75} \cdot 2.7 \mathrm{H}_{2} \mathrm{O}$ [27]. Even though the tetrahedral site is beyond the investigated route, the actual $\mathrm{Li}^{+}$and $\mathrm{Na}^{+}$route seems to be window center $\rightarrow$ tetrahedral site $\rightarrow$ window center. We emphasize that the potential barrier in this route is further suppressed as compared with the route, window center $\rightarrow$ nanocube center $\rightarrow$ window center.

\section{Battery Properties Mediated by $\mathrm{Li}^{+}$ Intercalation/Deintercalation}

3.1. Experiment. Thin films of $\mathrm{Li}_{0.68} \mathrm{Na}_{0.04} \mathrm{Ni}\left[\mathrm{Fe}(\mathrm{CN})_{6}\right]_{0.68}$ -5.1 $\mathrm{H}_{2} \mathrm{O}(\mathrm{M}=\mathrm{Ni}), \mathrm{Li}_{0.71} \mathrm{Na}_{0.13} \mathrm{Co}\left[\mathrm{Fe}(\mathrm{CN})_{6}\right]_{0.71} \cdot 3.8 \mathrm{H}_{2} \mathrm{O}(\mathrm{M}$ $=\mathrm{Co}), \quad \mathrm{Li}_{1.24} \mathrm{Mn}\left[\mathrm{Fe}(\mathrm{CN})_{6}\right]_{0.81} \cdot 3.0 \mathrm{H}_{2} \mathrm{O}(\mathrm{M}=\mathrm{Mn})$, and $\mathrm{Li}_{0.96} \mathrm{Na}_{0.88} \mathrm{Cd}\left[\mathrm{Fe}(\mathrm{CN})_{6}\right]_{0.96} \cdot 4.8 \mathrm{H}_{2} \mathrm{O}(\mathrm{M}=\mathrm{Cd})$ were synthesized by electrochemical deposition of the $\mathrm{Na}$ compounds on an indium tin oxide (ITO) transparent electrode and subsequent electrochemical substitution of $\mathrm{Li}^{+}$for $\mathrm{Na}^{+}$. In the $\mathrm{M}=\mathrm{Ni}, \mathrm{Co}$, and Cd compounds, [5] only the Fe site exhibits the redox reaction $\left(\mathrm{Fe}^{2+} \longleftrightarrow \mathrm{Fe}^{3+}\right)$, and, hence, a part of the $\mathrm{Na}$ sites is replaced by $\mathrm{Li}^{+}$. By contrast, two-electron reaction $\left(\mathrm{Fe}^{2+} \longleftrightarrow \mathrm{Fe}^{3+}\right.$ and $\mathrm{Mn}^{2+} \longleftrightarrow \mathrm{Mn}^{3+}$ ) takes place in the $\mathrm{M}=\mathrm{Mn}$ compound $[5,6]$. As a result, all the Na sites can be replaced by $\mathrm{Li}^{+}$. Chemical compositions of the films were determined by the inductively coupled plasma (ICP) method and CHN organic elementary analysis (Perkin-Elmer $2400 \mathrm{CHN}$ Elemental Analyzer). Details of the synthesis and characterization are described elsewhere [5].

The charge/discharge properties of the thin films were measured against $\mathrm{Li}$ in a beaker-type cell. The electrolyte was ethylene carbonate (EC)/diethyl carbonate (DEC) solution containing $1 \mathrm{~mol} / \mathrm{L} \mathrm{LiClO}_{4}$. The cutoff voltage was from 2.0 to $4.2 \mathrm{~V}$. The thickness and active areas of the films were $\sim 1 \mu \mathrm{m}$ and $1-2 \mathrm{~cm}^{2}$, respectively. The mass of each film was measured with a conventional electronic weighing machine after the film was carefully removed from the substrate with a microspatula. The experimental error of the mass is $10 \%$. The current density was set to be the same for the charge/discharge process.

3.2. Results. Figure 5 shows the charge/discharge curves of thin-film electrodes at various rates $(v)$. The discharge capacities at low $v(=0.1-1 \mathrm{C})$ coincides with the ideal value within the experimental error $(\sim 10 \%)$. In all the compounds, the discharge curves show plateaus at $\sim 3.4 \mathrm{~V}$. This plateau is ascribed to the reduction process at the Fe site $\left(\mathrm{Fe}^{3+} \rightarrow \mathrm{Fe}^{2+}\right)$ [5]. The plateau structure is discernible even at high $v(<30$ C). The capacities at $100 \mathrm{C}$ are $0.66(\mathrm{M}=\mathrm{Ni}), 0.31(\mathrm{Co}), 0.62$ $(\mathrm{Mn})$, and $0.74(\mathrm{Cd})$ of those at $1 \mathrm{C}$.

The Mn compound (Figure 5(c)) shows rather complicated behaviors. In the discharge curve, two additional plateaus are observed at $3.8 \mathrm{~V}$ and $3.6 \mathrm{~V}$. These plateaus are probably ascribed to the reduction process at the $\mathrm{Mn}$ site $\left(\mathrm{Mn}^{3+} \rightarrow \mathrm{Mn}^{2+}\right)[5,6]$. The oxidization (charge) process of the $\mathrm{Mn}$ compound is as follows. At the initial stage $\left(\mathrm{Li}_{1.24} \mathrm{Mn}^{2+}\left[\mathrm{Fe}^{2+}(\mathrm{CN})_{6}\right]_{0.81} \cdot 3.0 \mathrm{H}_{2} \mathrm{O}\right)$, the valence state is $\mathrm{Mn}^{2+}$ and $\mathrm{Fe}^{2+}$. In the first plateau at $3.4 \mathrm{~V}$, the $\mathrm{Fe}$ site is selectively oxidized to become $\mathrm{Li}_{0.44} \mathrm{Mn}^{2+}$ $\left[\mathrm{Fe}^{3+}(\mathrm{CN})_{6}\right]_{0.81} \cdot 3.0 \mathrm{H}_{2} \mathrm{O}$. In the second plateau at $3.8 \mathrm{~V}$, parts of the $\mathrm{Mn}$ sites are oxidized to become $\mathrm{Mn}^{2.44+}$ $\left[\mathrm{Fe}^{3+}(\mathrm{CN})_{6}\right]_{0.81} \cdot 3.0 \mathrm{H}_{2} \mathrm{O}$. Recently, Matsuda and Moritomo [28] found that thin film of $\mathrm{Na}_{1.32} \mathrm{Mn}\left[\mathrm{Fe}(\mathrm{CN})_{6}\right]_{0.83} \cdot 3.5 \mathrm{H}_{2} \mathrm{O}$ exhibits a high capacity of $114 \mathrm{mAh} / \mathrm{g}$ and an average operating voltage of $3.3 \mathrm{~V}$ against $\mathrm{Na}$ with a good cyclability. The electrolyte was propylene carbonate (PC) solution containing $1 \mathrm{~mol} / \mathrm{L} \mathrm{NaClO}_{4}$. Thus, the $\mathrm{Mn}$ compound exhibits reversible intercalation/deintercalation of $\mathrm{Li}^{+}$and $\mathrm{Na}^{+}$in organic solvent.

3.3. Interrelation with the Alkali Cation Potential. Generally speaking, the alkali cation intercalation process in the $\mathrm{Li}^{+}$ and $\mathrm{Na}^{+}$secondary batteries can be divided into the transfer process from the electrolyte to host framework and the migration process within the host framework. The former 


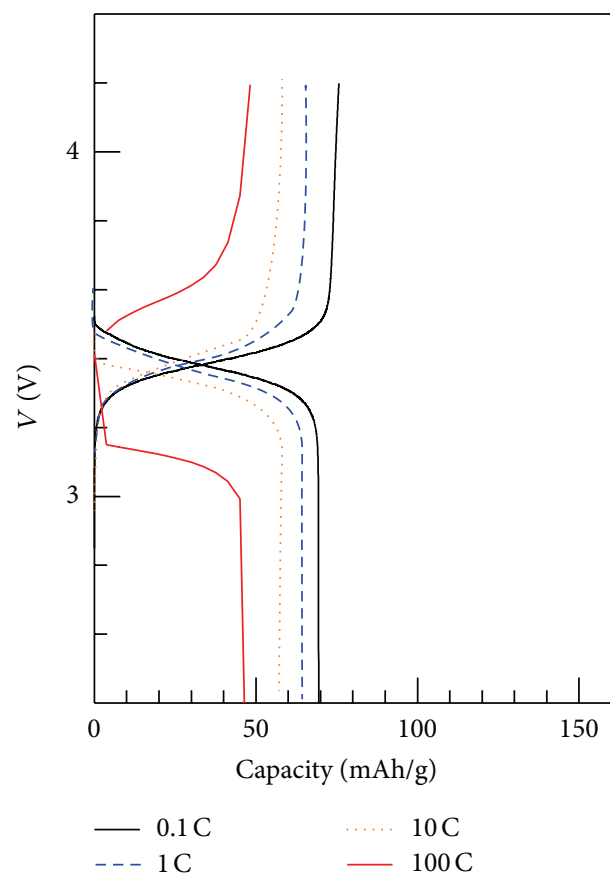

(a) $\mathrm{M}=\mathrm{Ni}$

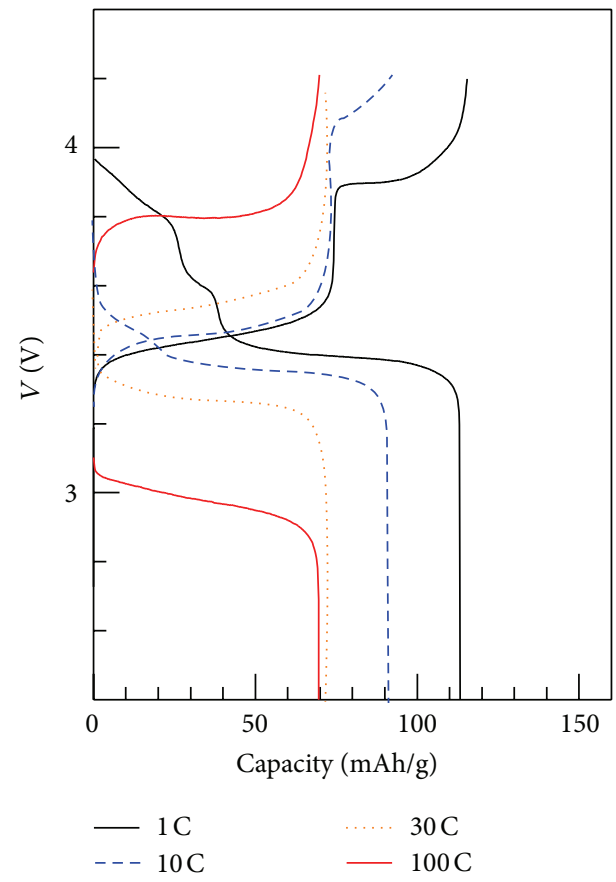

(c) $\mathrm{M}=\mathrm{Mn}$

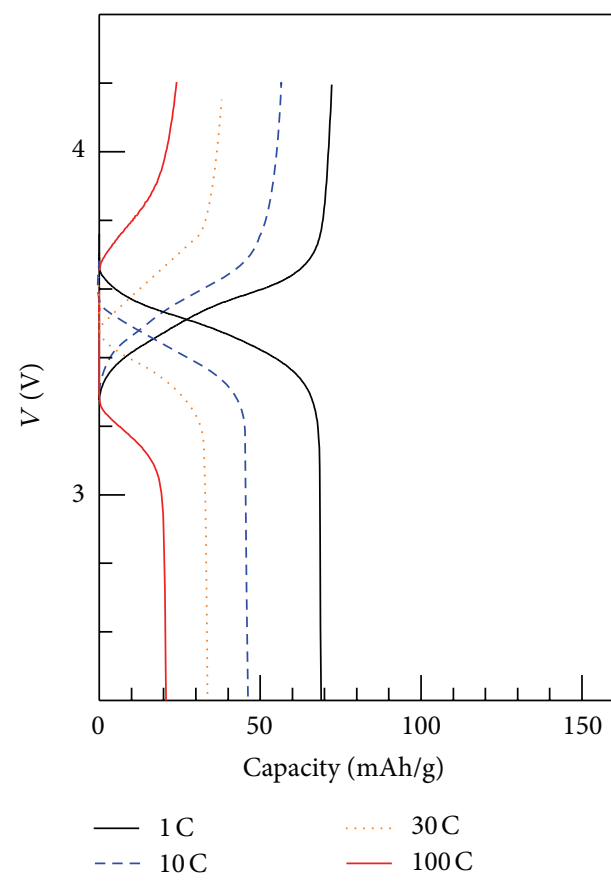

(b) $\mathrm{M}=\mathrm{Co}$

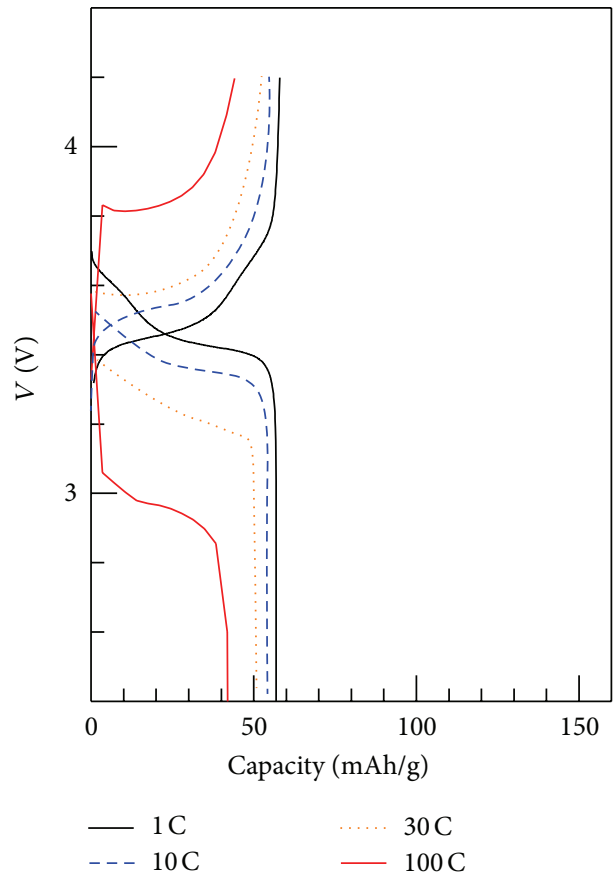

(d) $\mathrm{M}=\mathrm{Cd}$

Figure 5: Charge/discharge curve of thin-film electrodes of (a) $\mathrm{Li}_{0.68} \mathrm{Na}_{0.04} \mathrm{Ni}\left[\mathrm{Fe}(\mathrm{CN})_{6}\right]_{0.68} \cdot 5.1 \mathrm{H}_{2} \mathrm{O}$, (b) $\mathrm{Li}_{0.71} \mathrm{Na}_{0.13} \mathrm{Co}\left[\mathrm{Fe}(\mathrm{CN})_{6}\right]_{0.71} \cdot 3.8 \mathrm{H}_{2} \mathrm{O}$, (c) $\mathrm{Li}_{1.24} \mathrm{Mn}\left[\mathrm{Fe}(\mathrm{CN})_{6}\right]_{0.81} \cdot 3.0 \mathrm{H}_{2} \mathrm{O}$, and $(\mathrm{d}) \mathrm{Li}_{0.96} \mathrm{Na}_{0.88} \mathrm{Cd}\left[\mathrm{Fe}(\mathrm{CN})_{6}\right]_{0.96} \cdot 4.8 \mathrm{H}_{2} \mathrm{O}$ against $\mathrm{Li}$ at various rate $(v)$. The discharge curve at $v$ was measured after the charge process at $v$.

process usually accompanies the desolvation process and is complicated. In the latter process, the bare cation migrates toward the collective electrode with feeling the alkali cation potential. The latter process is essential for the capacity and rate properties of the active material. In the Prussian blue analogues, $\mathrm{Li}^{+}$and $\mathrm{Na}^{+}$rapidly migrate within the host framework as their potential barrier $(\Delta)$ is lower than or comparable to the thermal energy (Figure 3 ). This is the reason why the Prussian blue analogues work as the active material in $\mathrm{Li}^{+}$and $\mathrm{Na}^{+}$secondary batteries. 
On the other hand, the migration of $\mathrm{K}^{+}$and $\mathrm{Rb}^{+}$is impossible as $\Delta$ is much higher than the thermal energy. Actually, Moritomo et al. [23] reported that $\mathrm{K}^{+}$and $\mathrm{Rb}^{+}$ cannot intercalate into the $\mathrm{A}_{x} \mathrm{Co}\left[\mathrm{Fe}(\mathrm{CN})_{6}\right]_{0.90} 2.9 \mathrm{H}_{2} \mathrm{O}$ film from aqueous solution, whereas $\mathrm{Na}^{+}$can intercalate into the film. Of course, the alkali cation intercalation process is mainly governed by the transfer process from the electrolyte to the host framework. Nevertheless, the migration process plays a significant role even in the following case. They investigated the effect of the dipping of the film into an aqueous solution containing $\mathrm{K}^{+}$or $\mathrm{Rb}^{+}$and found that the procedure blocks the intercalation of $\mathrm{Na}^{+}$. This behavior is explained by the clogging of the cation routes at the surface region, as discussed in the next section.

\section{Electrochromism Mediated by $\mathrm{Na}^{+}$Transfer in All Solid Device}

4.1. Experiment. Thin films of $\mathrm{Na}_{0.72} \mathrm{Ni}\left[\mathrm{Fe}(\mathrm{CN})_{6}\right]_{0.68} \cdot 5.1 \mathrm{H}_{2} \mathrm{O}$ and $\mathrm{Na}_{0.79} \mathrm{Co}\left[\mathrm{Fe}(\mathrm{CN})_{6}\right]_{0.90} \cdot 2.9 \mathrm{H}_{2} \mathrm{O}$ were synthesized by electrochemical deposition on an ITO transparent electrode and subsequent electrochemical treatment. The electrolyte was aqueous solution containing of $1 \mathrm{~mol} / \mathrm{L} \mathrm{NaCl}$. The NiFe film was transparent, while the Co-Fe film was dark purple. Chemical compositions of the films were determined by the ICP method and $\mathrm{CNH}$ organic elementary analysis (Perkin-Elmer $2400 \mathrm{CHN}$ Elemental Analyzer). Details of the synthesis procedure and characterization were described in the literatures $[12,13]$.

The all-solid electrochromic device $[14,15]$ was made by connecting the surfaces of the $\mathrm{Na}_{0.72} \mathrm{Ni}\left[\mathrm{Fe}(\mathrm{CN})_{6}\right]_{0: 68} \cdot 5.1 \mathrm{H}_{2} \mathrm{O}$ $(560 \mathrm{~nm})$ and $\mathrm{Na}_{0.79} \mathrm{Co}\left[\mathrm{Fe}(\mathrm{CN})_{6}\right]_{0: 90} \cdot 2.9 \mathrm{H}_{2} \mathrm{O}(320 \mathrm{~nm})$ films without any electrolytes. The thickness of the films was determined by the cross-sectional scanning electron micrographs. The scanning probe microscope (SEM) images indicate that the Ni-Fe film consists of spherical grains, $\sim 50 \mathrm{~nm}$ in diameter, whereas the Co-Fe film consists of pyramidal grains, $100 \times 100 \mathrm{~nm}^{2}$ in area. The compositions after the short circuit are $\mathrm{Na}_{0.46} \mathrm{Ni}\left[\mathrm{Fe}(\mathrm{CN})_{6}\right]_{0: 68} \cdot 5.1 \mathrm{H}_{2} \mathrm{O}$ and $\mathrm{Na}_{1.03} \mathrm{Co}\left[\mathrm{Fe}(\mathrm{CN})_{6}\right]_{0: 90} \cdot 2.9 \mathrm{H}_{2} \mathrm{O}$, respectively. The $\mathrm{Na}^{+}$concentrations were estimated by IR spectra. Thus, the short circuit of the device induces the $\mathrm{Na}^{+}$transfer between the films. Before each measurement, the device was short circuited for several minutes.

4.2. Results. Figure 6(a) shows the I-t curves of the device under periodic rectangular voltage on the $\mathrm{M}=$ $\mathrm{Ni}$ side. The compositions after the short circuit are $\mathrm{Na}_{0.46} \mathrm{Ni}\left[\mathrm{Fe}(\mathrm{CN})_{6}\right]_{0: 68} \cdot 5.1 \mathrm{H}_{2} \mathrm{O}$ and $\mathrm{Na}_{1.03} \mathrm{Co}\left[\mathrm{Fe}(\mathrm{CN})_{6}\right]_{0: 90}$ $\cdot 2.9 \mathrm{H}_{2} \mathrm{O}$, respectively. At $0.6 \mathrm{~V}$, the magnitude of the positive current gradually decreases with $t$. The $0.6 \mathrm{~V}$ voltage changes the compositions into $\mathrm{Na}_{0.31} \mathrm{Ni}\left[\mathrm{Fe}(\mathrm{CN})_{6}\right]_{0: 68} \cdot 5.1 \mathrm{H}_{2} \mathrm{O}$ and $\mathrm{Na}_{1.53} \mathrm{Co}\left[\mathrm{Fe}(\mathrm{CN})_{6}\right]_{0: 90} \cdot 2.9 \mathrm{H}_{2} \mathrm{O}$, respectively. The $\mathrm{Ni}-\mathrm{Fe}$ film becomes dense yellow, while the Co-Fe film becomes more transparent. These color changes is ascribed to the valence change of the constituent transition metals. We note that the total current flow $(=0.16 \mathrm{e} / \mathrm{Ni}$ site $)$ in this process is comparable to the $\mathrm{Na}^{+}$transfer $(=0.15)$ of the
$\mathrm{Ni}-\mathrm{Fe}$ film. Reversely, the application of $-0.6 \mathrm{~V}$ on the $\mathrm{Ni}-\mathrm{Fe}$ side induces negative current. The $-0.6 \mathrm{~V}$ voltage changes the compositions into $\mathrm{Na}_{0.62} \mathrm{Ni}\left[\mathrm{Fe}(\mathrm{CN})_{6}\right]_{0: 68} \cdot 5.1 \mathrm{H}_{2} \mathrm{O}$ and $\mathrm{Na}_{0.81} \mathrm{Co}\left[\mathrm{Fe}(\mathrm{CN})_{6}\right]_{0: 90} \cdot 2.9 \mathrm{H}_{2} \mathrm{O}$, respectively. The Ni-Fe film becomes transparent, while the Co-Fe film becomes dark purple. We confirmed that the electrochromism is reversible for the periodic rectangular voltage by more than 100 cycles.

Figure $6(\mathrm{~b})$ shows the $I-t$ curves of the device at $+0.6 \mathrm{~V}$ on the $\mathrm{M}=\mathrm{Ni}$ side before and after dipping the films in an aqueous solution containing $\mathrm{K}^{+}\left(\mathrm{K}^{+}\right.$-treatment) Before the $\mathrm{K}^{+}$treatment, the magnitude of $I$ rapidly decreases and eventually becomes nearly zero at $\sim 10 \mathrm{~s}$. This clearly indicates that the device is not a resistor and the electrons cannot pass through the cyanide/cyanide interface. In other words, the $\mathrm{Na}^{+}$transfer between the films is a necessary condition for the current flow. The $\mathrm{K}^{+}$treatment significantly suppresses the magnitude of $I$, indicating that the treatment blocks the $\mathrm{Na}^{+}$transfer between the films.

4.3. Interrelation with the Alkali Cation Potential. The alkali cation intercalation of the present device is governed by the migration process within the host framework because the device has no electrolyte region. In the Prussian blue analogues, $\mathrm{Na}^{+}$rapidly migrates is within the host framework as $\Delta$ is lower than or comparable to the thermal energy (Figure 3). This is the reason why the device made by the Prussian blue analogues exhibits a rapid electrochromism.

On the other hand, the migration of $\mathrm{K}^{+}$is impossible as $\Delta$ is much higher than the thermal energy. At the $\mathrm{K}^{+}$ treatment, a part of $\mathrm{Na}^{+}$in the surface region is exchanged for the larger $\mathrm{K}^{+} . \mathrm{K}^{+}$cannot migrate into the inner part of the host framework or clogs the cation routes at the surface region. The clogged $\mathrm{K}^{+}$further blocks the intercalation of the smaller $\mathrm{Na}^{+}$. This mechanism explains well why the $\mathrm{K}^{+}$ treatment significantly suppresses the $\mathrm{Na}^{+}$transfer between the films.

\section{Elimination of $\mathrm{Cs}^{+}$from Aqueous Solution by Precipitation}

5.1. Experiment. The $\mathrm{Cs}^{+}$elimination performance from the aqueous solution was investigated for manganese and cobalt ferricyanides by the precipitation method [17]. We investigated the $\mathrm{Cs}^{+}$concentrations in aqueous solution before and after the precipitation treatment. In the high concentration region ( $>1 \mathrm{ppm})$, a Cs standard aqueous solution (1000 ppm $\mathrm{Cs}^{+}$in $0.5 \mathrm{~mol} / \mathrm{L} \mathrm{HNO}_{3}$ ) was used as the Cs source, and the $\mathrm{Cs}^{+}$concentrations were determined by mass spectroscopy inductively coupled plasma (MS-ICP) method. In the low concentration region $(\ll 1 \mathrm{ppm})$, the radioactive ${ }^{137} \mathrm{Cs}^{+}$was used as the Cs source, and the $\mathrm{Cs}^{+}$concentrations were determined by the radioactivity of the solution.

The precipitation treatment was schematically shown in Figure 7. $C_{i}$ and $C_{f}$ are the initial and final $\mathrm{Cs}^{+}$concentrations, respectively. First, $5 \mathrm{mmol} / \mathrm{L} \mathrm{Mn}^{\mathrm{II}} \mathrm{Cl}_{2}\left(\mathrm{Co}^{\mathrm{II}} \mathrm{Cl}_{2} \mathrm{a}\right)$ and $5 \mathrm{mmol} / \mathrm{L} \mathrm{mmol} / \mathrm{L} \mathrm{K}_{3}\left[\mathrm{Fe}^{\mathrm{III}}(\mathrm{CN})_{6}\right]$ were added to the aqueous solution. Then, the solution was mixed, agitated for $5 \mathrm{~min}$, and ultrasonicated for $5 \mathrm{~min}$. The precipitates in the solution 


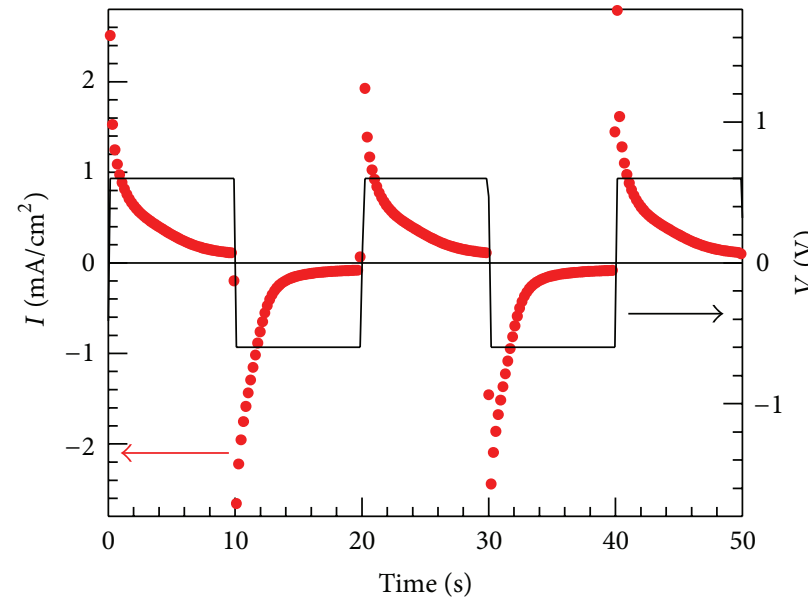

(a) $\mathrm{ITO} / \mathrm{Ni}-\mathrm{Fe} / \mathrm{Co}-\mathrm{Fe} / \mathrm{ITO}$

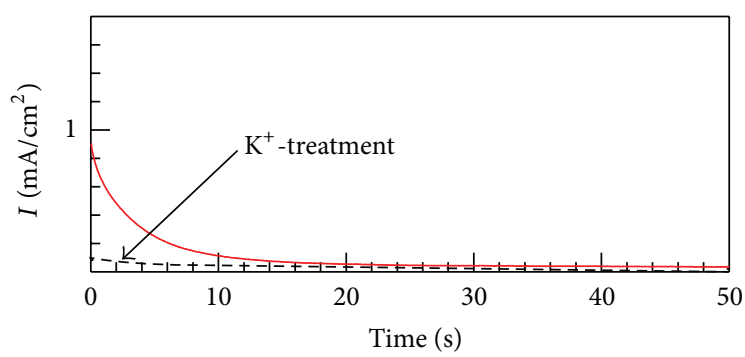

(b)

Figure 6: (a) Current density (I) of ITO/ $\mathrm{Na}_{0.72} \mathrm{Ni}\left[\mathrm{Fe}(\mathrm{CN})_{6}\right]_{0: 68} \cdot 5.1 \mathrm{H}_{2} \mathrm{O}(560 \mathrm{~nm}) / \mathrm{Na}_{0.79} \mathrm{Co}\left[\mathrm{Fe}(\mathrm{CN})_{6}\right]_{0: 90} \cdot 2.9 \mathrm{H}_{2} \mathrm{O}(320 \mathrm{~nm}) / \mathrm{ITO}$ device against time $(t)$ under periodic rectangular voltage $(V)$ on the $\mathrm{M}=\mathrm{Ni}$ side. (b) $I-t$ curves at $0.6 \mathrm{~V}$ of the device before and after the $\mathrm{K}^{+}$treatment.

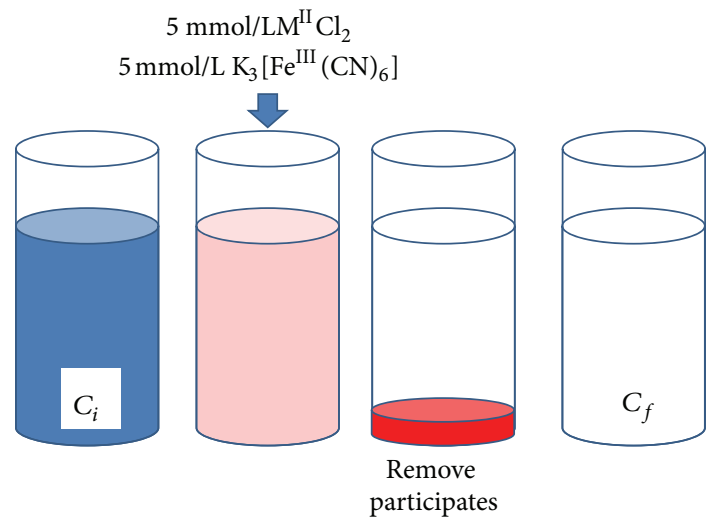

Figure 7: Schematic illustration of precipitation treatment. $5 \mathrm{mmol} / \mathrm{L} \mathrm{M}^{\mathrm{II}} \mathrm{Cl}_{2}(\mathrm{M}=\mathrm{Co}$ and $\mathrm{Mn})$ and $5 \mathrm{mmol} / \mathrm{L} \mathrm{mmol} / \mathrm{L}$ $\mathrm{K}_{3}\left[\mathrm{Fe}^{\mathrm{III}}(\mathrm{CN})_{6}\right]$ were added to the aqueous solution, and, then, the precipitates were removed. $C_{i .}$ and $C_{f}$ are the initial and final $\mathrm{Cs}^{+}$ concentrations, respectively.

were separated and collected with a cyclotron separator. $C_{f}$ was determined after the percolation treatment of the solution with a $0.2 \mu \mathrm{m}$ polytetrafluoroethylene (PTFE) filter.

5.2. Results and Discussion. Figure 8 shows the Cs concentration before (filled circles) and after (open circles) the precipitation treatment. In the manganese ferricyanide (open circles), the simple precipitation procedure eliminates $\mathrm{Cs}^{+}$ from the aqueous solution by 4 or 5 orders. We emphasize that the manganese ferricyanide exhibits an excellent performance even at low $\mathrm{Cs}^{+}$concentration in the ppt $\left(=10^{-6} \mathrm{ppm}\right)$ region.

We investigated the structure and the grain size of the precipitates from $5 \mathrm{mmol} / \mathrm{L} \mathrm{K}_{3}\left[\mathrm{Fe}^{\mathrm{III}}(\mathrm{CN})_{6}\right]$ and $5 \mathrm{mmol} / \mathrm{L}$ $\mathrm{Mn}^{\mathrm{II}} \mathrm{Cl}_{2}$. The $\mathrm{X}$-ray powder diffraction patterns were

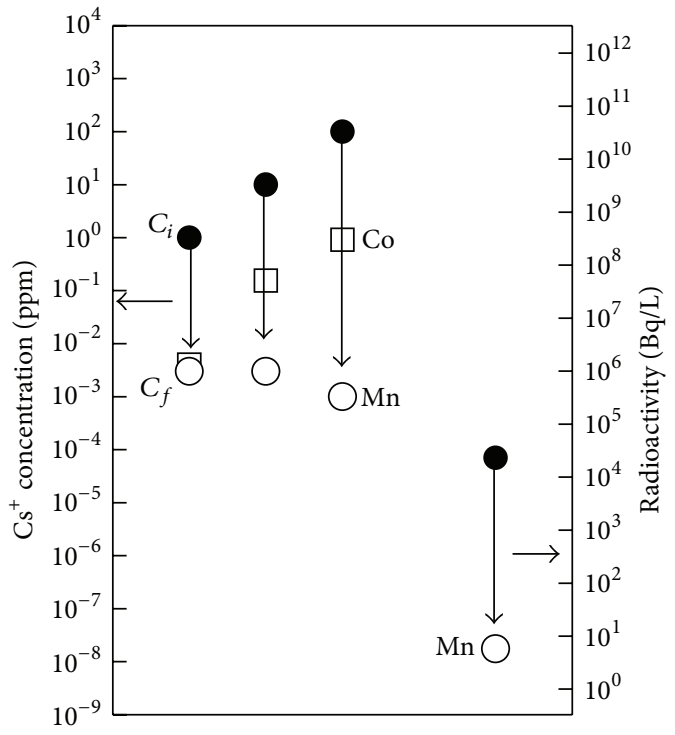

FIGURE 8: $\mathrm{Cs}^{+}$concentration before (filled circles) and after (open symbols) the precipitation treatment with $5 \mathrm{mmol} / \mathrm{L} \mathrm{K}_{3}\left[\mathrm{Fe}^{\mathrm{III}}(\mathrm{CN})_{6}\right]$ and $5 \mathrm{mmol} / \mathrm{L} \mathrm{Mn}^{\mathrm{II}} \mathrm{Cl}_{2}$. $\left(\mathrm{Co}^{\mathrm{II}} \mathrm{Cl}_{2}\right)$. Open circle and squares are for manganese and cobalt ferricyanides, respectively.

obtained at BL02B2 beamline [29] at SPring-8. The X-ray powder diffraction patterns revealed that the precipitates belong to the face-centered cubic. The lattice constants $(a)$ are distributed from 1.056 to $1.060 \mathrm{~nm}$, which are close to the value $\left(=1.05561 \mathrm{~nm} \mathrm{[22])}\right.$ of $\mathrm{Na}_{1.32} \mathrm{Mn}\left[\mathrm{Fe}(\mathrm{CN})_{6}\right]_{0.83} \cdot 3.6 \mathrm{H}_{2} \mathrm{O}$. This observation suggests that the precipitates are manganese ferricyanide, $\mathrm{Cs}_{x} \mathrm{Mn}\left[\mathrm{Fe}(\mathrm{CN})_{6}\right]_{y}$. We further estimated the domain size $(\sim 300 \mathrm{~nm})$ by Scherrer's equation. Thus, manganese ferricyanide imprisons $\mathrm{Cs}^{+}$into large domain $(\sim 300 \mathrm{~nm})$ and, hence, can isolate them from the environment for a long time. 
TABLE 3: Structural parameters of $\mathrm{Cs}_{0.31} \mathrm{Mn}\left[\mathrm{Fe}(\mathrm{CN})_{6}\right]_{0.79} \cdot 2.9 \mathrm{H}_{2} \mathrm{O}$ obtained the Rietveld analysis with the $(F m 3 m ; Z=4)$ model. The reliable parameters were $R_{\mathrm{wp}}=6.4 \%, R_{I}=8.0 \%$, and $S=2.29$. The lattice constant is $a=1.06057(2) \mathrm{nm} . \mathrm{O}_{1}$ and $\mathrm{O}_{z}$ are ligand and zeolite oxygens, respectively.

\begin{tabular}{lcccccc}
\hline Atom & Site & $g$ & $x$ & $y$ & $z$ & $B\left(\mathrm{~A}^{2}\right)$ \\
\hline $\mathrm{Cs}$ & $8 \mathrm{c}$ & $0.155(2)$ & $1 / 4$ & $1 / 4$ & $1 / 4$ & $2.33(5)$ \\
$\mathrm{Fe}$ & $4 \mathrm{a}$ & $0.79(1)$ & 0 & 0 & 0 & 2.33 \\
$\mathrm{Mn}$ & $4 \mathrm{~b}$ & 1 & $1 / 2$ & $1 / 2$ & $1 / 2$ & 2.33 \\
$\mathrm{C}$ & $24 \mathrm{e}$ & 0.79 & $0.201(1)$ & 0 & 0 & $4.47(17)$ \\
$\mathrm{N}$ & $24 \mathrm{e}$ & 0.79 & $0.304(1)$ & 0 & 0 & 4.47 \\
$\mathrm{O}_{1}$ & $24 \mathrm{e}$ & 0.21 & 0.201 & 0 & 0 & 4.47 \\
$\mathrm{O}_{z}$ & $32 \mathrm{f}$ & $0.200(4)$ & 0.2 & 0.2 & 0.2 & 4.47 \\
\hline
\end{tabular}

5.3. Interrelation with the Alkali Cation Potential. First, let us investigate the $\mathrm{Cs}^{+}$site by the Rietveld analysis (RietanFP [30]) of the precipitates from the $100 \mathrm{ppm} \mathrm{Cs}^{+}$solution. We neglect $\mathrm{H}^{+}$in the structural analysis. We refined the occupancies $(g)$ of $\mathrm{Cs}, \mathrm{Fe}(\mathrm{CN})_{6}$, and $\mathrm{O}_{z}$. The obtained parameters were listed in Table 3 . The estimated oxygen concentration $(z=2.9)$ is reasonable. We found that $85 \%$ of the nanocubes were occupied by $\mathrm{O}_{z}$. The residual rooms are comparable to the Cs concentration $(=15 \%)$. This structural analysis indicates that the $\mathrm{Cs}^{+}$is trapped at the nanocube center of the host framework.

The $\mathrm{Cs}^{+}$capture process within the host framework is inseparable with the crystallization process from the aqueous solution of $\mathrm{Cs}^{+},\left[\mathrm{Fe}^{\mathrm{III}}(\mathrm{CN})_{6}\right]^{3-}$, and $\mathrm{Mn}^{\mathrm{II}}$. In this sense, the $\mathrm{Cs}^{+}$capture performance is determined by the crystallization energy or, more precisely, the energy difference between $\mathrm{CsMn}^{\mathrm{II}}\left[\mathrm{Fe}^{\mathrm{III}}(\mathrm{CN})_{6}\right]$ and $\mathrm{Mn}^{\mathrm{II}}\left[\mathrm{Fe}^{\mathrm{III}}(\mathrm{CN})_{6}\right]_{2 / 3}+\mathrm{Cs}^{+}$ $+1 / 3\left[\mathrm{Fe}^{\mathrm{III}}(\mathrm{CN})_{6}\right]^{3-}$. What we can say from the alkali cation potential (Figure 3 ) is that the captured $\mathrm{Cs}^{+}$is hard to escape from the nanocube due to the high- $\Delta$ at the surrounding windows. This partly explains the excellent performance of manganese ferricyanide.

Here, let us crudely discuss the interrelation between $\Delta$ and the crystallization energy. Roughly speaking, the magnitude of $\Delta$ is a measure of the short-range atomic repulsive interaction between $\mathrm{Cs}^{+}$and the host framework. Then, the smaller $\Delta$ becomes, the larger the crystallization gain by the $\mathrm{Cs}^{+}$capture becomes. $\Delta$ of the $\mathrm{Mn}(a=$ $1.05561 \mathrm{~nm}$ ) compound is $\sim 1 \mathrm{eV}$ smaller than that of the Co $(a=0.93440 \mathrm{~nm})$ compound (see Figure 4). This trend is consistent with the higher performance in $\mathrm{Mn}^{\mathrm{II}}-\left[\mathrm{Fe}^{\mathrm{III}}(\mathrm{CN})_{6}\right]$ as compared with $\mathrm{Co}^{\mathrm{II}}-\left[\mathrm{Fe}^{\mathrm{III}}(\mathrm{CN})_{6}\right]$ (see Figure 8). In addition, Omura and Moritomo [17] systematically investigated the $\mathrm{Cs}^{+}$capture performance in $\mathrm{M}^{\mathrm{II}}-\left[\mathrm{Fe}^{\mathrm{III}}(\mathrm{CN})_{6}\right](\mathrm{M}=\mathrm{Fe}$, $\mathrm{Ni}, \mathrm{Cu}, \mathrm{Zn}, \mathrm{Co}$, and $\mathrm{Mn}$ ) and found a positive correlation with the ionic radium $\left(r_{\mathrm{M}}\right)$ of $\mathrm{M}^{\mathrm{II}}$. This positive correlation is also interpreted in terms of the crystallization gain by the $\mathrm{Cs}^{+}$capture.

\section{Summary}

We performed an ab initio total energy calculation to derive the alkali cation potential in the Prussian blue analogues,
$\mathrm{A}_{x} \mathrm{M}\left[\mathrm{Fe}(\mathrm{CN})_{6}\right]_{y} z \mathrm{H}_{2} \mathrm{O}(\mathrm{A}=\mathrm{Li}, \mathrm{Na}, \mathrm{K}, \mathrm{Rb}$, and Cs; $\mathrm{M}=\mathrm{Co}$, $\mathrm{Ni}, \mathrm{Mn}$, and $\mathrm{Cd}$ ). We discussed the interrelation between the alkali cation potential and the functionalities observed in the Prussian blue analogues, that is, (a) battery properties mediated by $\mathrm{Li}^{+}$intercalation/deintercalation, (b) electrochromism mediated by $\mathrm{Na}^{+}$transfer in all solid device, and (c) elimination of $\mathrm{Cs}^{+}$from aqueous solution by precipitation.

\section{Acknowledgments}

This work was supported by the Canon Foundation Mitsubishi foundation, and also by a Grant-in-Aid for Scientific Research (no. 21244052) from the Ministry of Education, Culture, Sports, Science, and Technology, Japan. The synchrotron-radiation X-ray powder diffraction experiments were performed at the BL02B2 beamline of SPring- 8 with the approval of the Japan Synchrotron Radiation Research Institute (JASRI). The elementary analysis of the films was performed at the Chemical Analysis Division, Research Facility Center for Science and Engineering, University of Tsukuba. We appreciate Professor K. Sueki (Radioisotope Center, University of Tsukuba), Dr. A. Omura, and Dr. T. Matsuda for their help in the measurement of the $\mathrm{Cs}^{+}$concentrations in aqueous solution with the use of radioactive ${ }^{137} \mathrm{Cs}$.

\section{References}

[1] N. Imanishi, T. Morikawa, J. Kondo et al., "Lithium intercalation behavior into iron cyanide complex as positive electrode of lithium secondary battery," Journal of Power Sources, vol. 79, no. 2, pp. 215-219, 1999.

[2] N. Imanishi, T. Morikawa, J. Kondo et al., "Lithium intercalation behavior of iron cyanometallates," Journal of Power Sources, vol. 81-82, pp. 530-534, 1999.

[3] M. Okubo, D. Asakura, Y. Mizuno et al., "Switching redoxactive sites by valence tautomerism in prussian blue analogues $\mathrm{A}_{x} \mathrm{Mn}_{y}\left[\mathrm{Fe}(\mathrm{CN})_{6}\right] \cdot \mathrm{nH}_{2} \mathrm{O}(\mathrm{A}=\mathrm{K}, \mathrm{Rb})$ : robust frameworks for reversible Li storage," Journal of Physical Chemistry Letters, vol. 1, no. 14, pp. 2063-2071, 2010.

[4] T. Matsuda and Y. Moritomo, "Thin film electrode of Prussian blue analogue for Li-ion battery," Applied Physics Express, vol. 4, no. 4, Article ID 047101, 3 pages, 2011.

[5] Y. Moritomo, M. Takachi, Y. Kurihara, and T. Matsuda, "Thin film electrode of Prussian blue analogue with fast $\mathrm{Li}^{+}$intercalation," Applied Physics Express, vol. 5, no. 4, Article ID 041801, 3 pages, 2012.

[6] T. Matsuda and Y. Moritomo, "Two-electron reaction without structural phase transition in nanoporous cathode materials," Journal of Nanotechnology, vol. 2012, Article ID 569814, 8 pages, 2012.

[7] Y. Moritomo, Z. H. Zhu, M. Takachi, and T. Matsuda, "Fast discharge process of thin film electrode of Prussian ble analogues," Japanese Journal of Applied Physics, vol. 51, no. 10, Article ID 107301, 4 pages, 2012.

[8] M. Takachi, Y. Kurihara, and Y. Moritomo, "Channel size dependence of $\mathrm{Li}^{+}$insertion/extraction in nanoporous hexacyanoferrates," Materials Science and Engineering B, vol. 2, no. 8, pp. 452-457, 2012. 
[9] A. Gotoh, H. Uchida, M. Ishizaki et al., "Simple synthesis of three primary colour nanoparticle inks of Prussian blue and its analogues," Nanotechnology, vol. 18, no. 34, Article ID 345609, 2007.

[10] S. Hara, H. Tanaka, T. Kawamoto et al., "Electrochromic thin film of Prussian blue nanoparticles fabricated using wet process," Japanese Journal of Applied Physics, vol. 46, no. 36-40, pp. L945-L947, 2007.

[11] F. Nakada, H. Kamioka, Y. Moritomo, J. E. Kim, and M. Takata, "Electronic phase diagram of valence-controlled cyanide: $\mathrm{Na}_{0.84-\delta} \mathrm{Co}\left[\mathrm{Fe}(\mathrm{CN})_{6}\right]_{0.71} \cdot 3.8 \mathrm{H}_{2} \mathrm{O}(0<\delta<0.61)$," Physical Review $B$, vol. 77, no. 22, Article ID 224436, 2008.

[12] T. Shibata, F. Nakada, H. Kamioka, and Y. Moritomo, "Magnetic and electronic properties of valence-controlled Ni-Fe cyanide," Journal of the Physical Society of Japan, vol. 77, no. 10, Article ID 104714, 5 pages, 2008.

[13] K. Igarashi, F. Nakada, and Y. Moritomo, "Electronic structure of hole-doped Co-Fe syanide $\mathrm{Na}_{1 \cdot 60-\delta \mathrm{Co}}\left[\mathrm{Fe}(\mathrm{CN})_{6}\right] 0.90 \cdot 2.9 \mathrm{H}_{2} \mathrm{O}$ $(0<\delta<0.85)$," Physical Review B, vol. 78, no. 23, Article ID 235106, 6 pages, 2008.

[14] T. Shibara and Y. Moritomo, "Quick response of all solid electrochromic device," Applied Physics Express, vol. 2, no. 10, Article ID 105502, 3 pages, 2008.

[15] Y. Moritomo and T. Shibara, "Electric pressure-induced ferromagnetism mediated by Prussian blue junction," Applied Physics Letters, vol. 94, no. 4, Article ID 043502, 3 pages, 2009.

[16] Y. Kurihara, H. Funashima, M. Ishida et al., "Electronic structure of hole-doped transition metal cyanides," Journal of the Physical Society of Japan, vol. 79, no. 4, Article ID 044710, 2010.

[17] A. Omura and Y. Moritomo, "Cs ${ }^{+}$trapping in size-controlled nanospaces in hexacyanoferrates," Applied Physics Express, vol. 5, no. 5, Article ID 057101, 3 pages, 2012.

[18] T. Matsuda, J. E. Kim, K. Ohoyama, and Y. Moritomo, "Universal thermal response of the Prussian blue lattice," Physical Review B, vol. 79, no. 17, Article ID 172302, 4 pages, 2009.

[19] K. Itaya, I. Uchida, and V. D. Neff, "Electrochemistry of polynuclear transition metal cyanides: prussian blue and its analogues," Accounts of Chemical Research $®$, vol. 19, no. 6, pp. 162-168, 1986.

[20] N. Bagkar, C. A. Betty, P. A. Hassan, K. Kahali, J. R. Bellare, and J. V. Yakhmi, "Self-assembled films of nickel hexacyanoferrate: electrochemical properties and application in potassium ion sensing," Thin Solid Films, vol. 497, no. 1-2, pp. 259-266, 2006.

[21] W. Jin, A. Toutianoush, M. Pyrasch et al., "Self-assembled films of Prussian blue and analogues: structure and morphology, elemental composition, film growth, and nanosieving of ions," Journal of Physical Chemistry B, vol. 107, no. 44, pp. 12062-12070, 2003.

[22] M. Pyrasch, A. Toutianoush, W. Jin, J. Schnepf, and B. Tieke, "Self-assembled films of Prussian Blue and analogues: optical and electrochemical properties and application as ion-sieving membranes," Chemistry of Materials, vol. 15, no. 1, pp. 245-254, 2003.

[23] Y. Moritomo, K. Igarashi, J. Kim, and H. Tanaka, "Size dependent cation channel in nanoporous prussian blue lattice," Applied Physics Express, vol. 2, no. 8, Article ID 085001, 3 pages, 2009.

[24] P. Blaha, K. Schwarz, G. K. H. Madsen, D. Kvasnicka, and J. Luitz, WIEN2k, an augmented plane wave ${ }^{+}$local orbital program for calculating crystal properties, Karlheinz Schwarz,Technical University of Vienna, Vienna, Austria, 2001.
[25] J. P. Perdew, K. Burke, and M. Ernzerhof, "Generalized gradient approximation made simple," Physical Review Letters, vol. 77, no. 18, pp. 3865-3868, 1996.

[26] Y. Moritomo, T. Matsuda, Y. Kurihara, and J. Kim, "Cubic-rhombohedral structural phase transition in $\mathrm{Na}_{1.32} \mathrm{Mn}\left[\mathrm{Fe}(\mathrm{CN})_{6}\right]_{0.83} \cdot 3.6 \mathrm{H}_{2} \mathrm{O}$," Journal of the Physical Society of Japan, vol. 80, no. 7, Article ID 074608, 2011.

[27] J. E. Kim, K. Kato, M. Takata, T. Shibata, and Y. Moritomo, "Guest-host interaction of $\mathrm{K}_{0.34} \mathrm{Co}\left[\mathrm{Fe}(\mathrm{CN})_{6}\right]_{0.75} \cdot \mathrm{zH}_{2} \mathrm{O}$ as investigated by a charge-density analysis," Physical Review B, vol. 79, no. 13, Article ID 132105, 2009.

[28] T. Matsuda, M. Takachi, and Y. Moritomo, "A sodium manganese ferrocyanide thin film for Na-ion batteries," Chemical Communications, vol. 49, pp. 2750-2752, 2013.

[29] E. Nishibori, M. Takata, K. Kato et al., "The large DebyeScherrer camera installed at SPring-8 BL02B2 for charge density studies," Nuclear Instruments and Methods in Physics Research A, vol. 467-468, Part 2, pp. 1045-1048, 2001.

[30] F. Izumi and K. Momma, "Three-dimensional visualization in powder diffraction," Solid State Phenomena, vol. 130, pp. 15-20, 2007. 

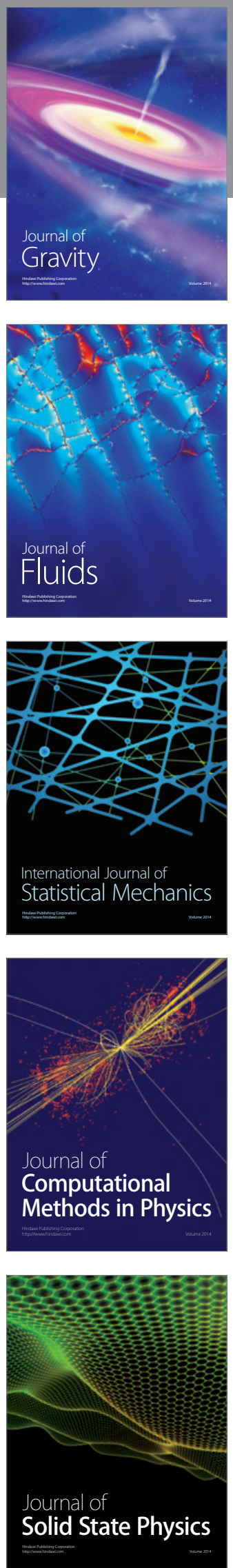

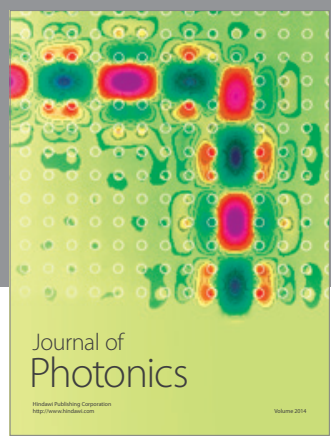

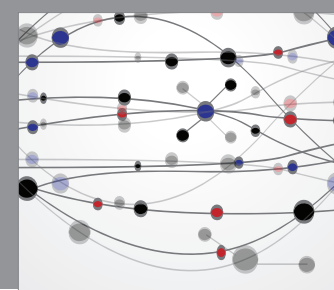

The Scientific World Journal

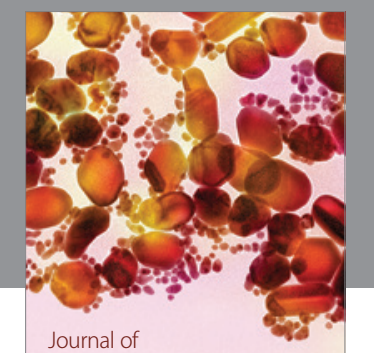

Soft Matter
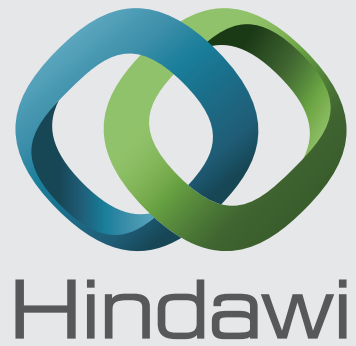

Submit your manuscripts at

http://www.hindawi.com
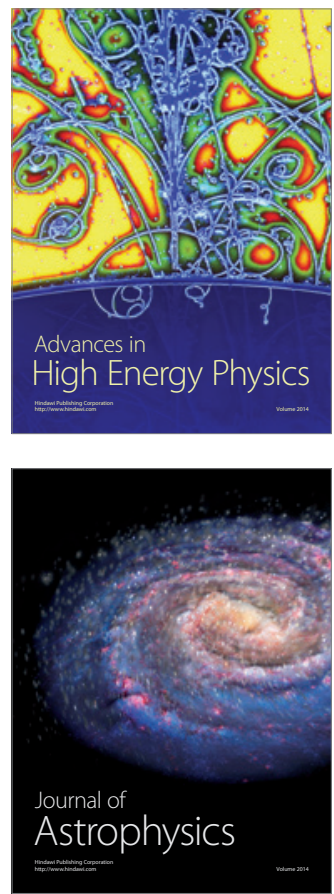
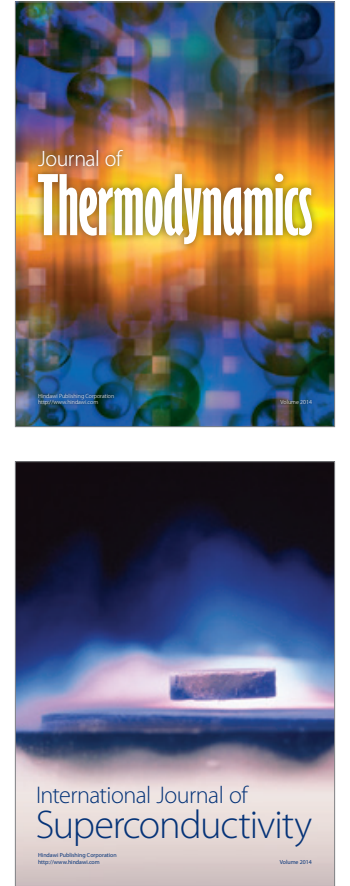
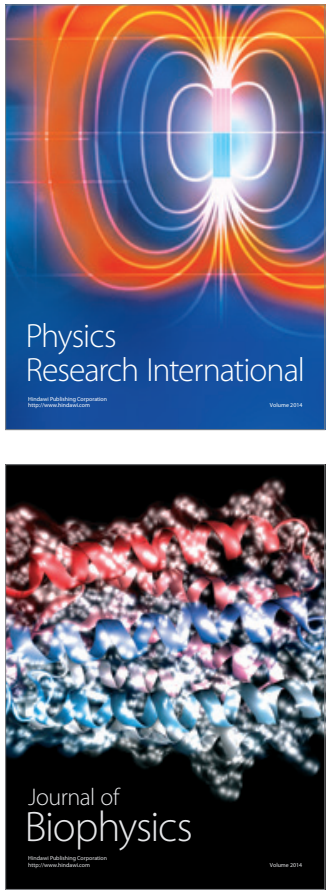
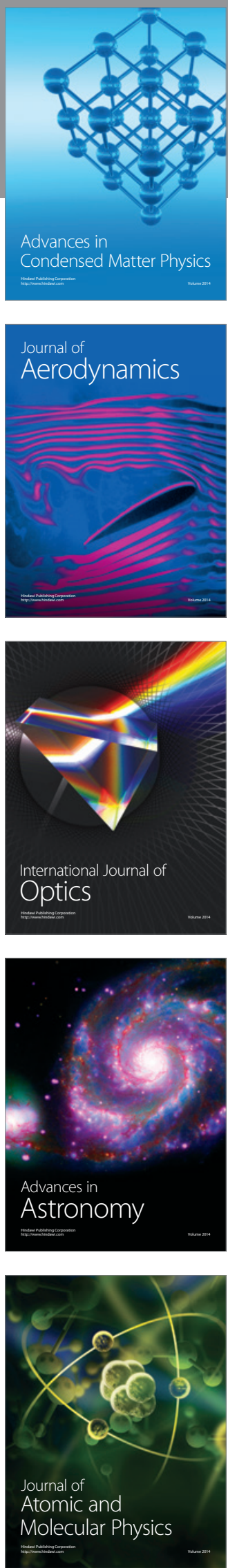